\title{
What is Visual Quantum Learning Effect to Student Learning Results
}

\author{
Suryanti, Cendera, Mintohari, Farida Istianah \\ Universitas Negeri Surabaya \\ Surabaya, Indonesia \\ suryanti@unesa.ac.id
}

\begin{abstract}
The problem faced by developing countries, including Indonesia, are still the lowest thinking of student ability, proved the low value of the PISA test. An alternative to improving the problem of student ability is the application of visual quantum learning. The research aims to determine how the influence of visual quantum learning on the result of learning. Which is this research experimental with pretest-posttest control group design? Data collection was done using the test method. The test used is a written that is a matter of multiple choice with 4 answers choices. The data obtained than in the analysis using a t-test. The result showed that students learning outcomes in the learning using visual quantum learning with an average score of 80.74 compared to students whose learning using classical learning, with an average of 78.28. this is reinforced by the results of the t-test analysis showing significant differences between students who were treated through visual quantum learning models with students who were not treated through classical learning. The results of this research can be concluded that visual quantum learning model learning model influences the 4th grade of science learning outcomes in elementary school. In order for science learning to obtain good results, then learning can be done by using visual quantum learning of models.
\end{abstract}

\section{Keywords_quantum learning; learning result}

\section{INTRODUCTION}

The results of learning and how to obtain the ability and information are interrelated in accordance with the specific objectives expected. Learning outcomes are the abilities students have after he absorbs and taught the learning process [1]. This is in agreement with Purnomo (2016: 22) which states that the acquisition of student learning outcomes is not about cognitive aspects only, but also about the application, effective aspects that include behavior and internalization of values that need to be inculcated and educated through the subjects given.

Changes in behavior that occurs as a result of learning activities that have been done by individuals. The change is the result that has been achieved through the learning process. Because learning is a process, then from the process will produce a result, and the outcome of the learning process is in the form of learning outcomes. According to Syaiful Bahri Djamarah [2], the results of learning are "changes that occur as a result of learning activities that have been done by individuals". Changes in behavior experienced by students depending on what he learned over a period of time. Result obtained by students usually behavioral changes concerning cognitive, effective, and psychomotor aspects symbolized by numbers or values.

Based on the results of a survey conducted by PISA in 2015, Indonesia experienced an increase in mathematics and science. Although Indonesia experienced a significant increase in performance, the achievement, in general, is still below the OECD average. Based on the results of a survey conducted by TIMSS in 2015 in the fourth grade of primary school, it is concluded that the fourth graders of elementary school are still not encouraging. The factors that influence the achievement of TIMSS assessment result are curriculum, learning, teacher, parent/family, student attitude, background, and infrastructure. According to TIMSS, about $75 \%$ of items tested have been taught in grade IV of elementary school, but the deepening of students' understanding is lacking. The results of the measurement of student achievement based on the UN was in line with the achievements of PISA and TIMSS. Thus, improving the quality of education can be encouraged through a good assessment.

By improving the quality of education it is necessary to improve, one of them through quality learning. One way that science learning in the classroom can improve is by using a quantum learning model, where this learning model involves everything. Based on observations that have been done, teaching and learning activities conducted in schools on average using visual learning styles. Visual learning style is very dominant among the fourth-grade teachers. In learning, the dominant teacher uses a blackboard as a visual learning medium.

This was also supported by the results of questionnaires, at two random schools, that students using visual learning styles of $55.26 \%$, higher than auditory learning style $4836 \%$ and kinesthetic $48.6 \%$. In other schools also obtained the results of the questionnaire, in $60.2 \%$ visual, auditory $52 \%$, and kinesthetic $47.3 \%$. Overall, students have a dominant visual learning style in learning, but limited student activity will place and time in science learning make students feel tense and bored. The saturation of these students resulted in a decline in 
student learning outcomes. The tension experienced by students inhibits the work of the brain and the interest of students in learning. This is what makes student learning outcomes especially in cognitive aspects that tend to be low.

According to Piaget's developmental theory, where grade IV students at 7-11 years have the ability to sort objects, name and identify objects, and the ability to consider problems from various aspects of problem-solving. In solving this problem, students use visual modalities as a way of receiving information provided by teachers. This is in line with the theory of Vygotsky better known as the theory of constructivism. According to Vygotsky's cognitive development theory, one gives great support to the individual during the early stages of learning and then releases help so that the individual is capable of being responsible and able to consider various attempts at solving the problem. One of Vygotsky's often-heard messages is "to help children develop knowledge in a truly meaningful way is to integrate concepts and procedures through demonstrations.

Therefore, one of the learning models that is comfortable and fun, and in accordance with the theories is the Visual Quantum Visual Learning Model. The Quantum Learning Model incorporates all the elements that exist within the student's self and surroundings. The Quantum Learning Model links all aspects to maximize learning moments. The Quantum Learning Model centers on the dynamic relationship between students and the environment as a design and foundation for learning [3].

The quantum learning model pervades the student world, interacts, completes less than targeted learning, obtains a more inherent material understanding and prevents misconception of knowledge. The quantum learning model creates relevance for students and the dominating learning process is more like in everyday life. One way to build and bridge the world of students with teachers is through learning modalities. Every person's learning modalities are not the same, everyone has at least one dominant modality to them. The modality of learning there is three types, namely Visual, Auditory, and Kinesthetic (VAK). Based on the data obtained, the researchers focus on the visual modalities as the dominant modalities used by students.

In elementary education (SD), students study a number of disciplines. One of them is IPA. IPA is a study that examines all aspects of the material and nature around systematically. Samatowa (2011) states that science is a science that examines everything that happens in nature, which is structured based on the results of research and observations made by humans. Science or science learning provides a real experience for students to develop self-competence and understand the phenomena that occur in the natural environment. Science learning requires observation and real practice in the field, so it is not just material presented by the teacher. Al Hamdani [4] conducted a study of three different learning styles (visual, auditory, and kinesthetic) and the results of the study showed that student learning styles will improve their learning and understanding and based on learning outcomes an effective instructive model is suggested. This model is designed to promote active learning and improve student learning regardless of their inconsistency.

Like Al Hamdani and Ni Luh Putu's opinion, Oflaz [5] argues that students participate actively and do group work well if teachers use student learning styles to be considered when forming a group. It can balance student activity in concentrating, motivating and performing well in learning. The need for students to actively participate in the surrounding environment indicates the need for exposure to different learning styles, strategies and skills of creative and critical thinking. Awareness of learning styles and the best strategies can be done by improvising to fit each individual. Students will be encouraged to challenge their own perceived limitations when exposed to such varied learning styles. Thus the impetus for such variation in student learning styles lies in the varied teaching approach adopted by the teacher who can create that awareness among the students and the optimal learning outcomes can be achieved.

Based on the background explanation, then held research about the Influence of Visual Quantity Learning Model to the Learning Outcomes of Science Class IV in SD. So the purpose of this study is to determine the effect of visual quantum learning model on the results of science learning grade IV in SD.

\section{METHOD}

\section{A. Methodology}

The research was an experimental research using pretestposttest control group design, that is experiments conducted on two randomly selected groups. One group was given pretest, treatment, and posttest, while one other group was given pretest and posttest, not treated.

$\begin{array}{cccc}\mathrm{R} & \mathrm{O}_{1} & \mathrm{X} & \mathrm{O}_{2} \\ \mathrm{R} & \mathrm{O}_{3} & & \mathrm{O}_{4}\end{array}$

\begin{tabular}{|llll|}
\hline $\mathrm{R}$ & $\mathrm{O}_{1}$ & $\mathrm{X}$ & $\mathrm{O}_{2}$ \\
$\mathrm{R}$ & $\mathrm{O}_{3}$ & & $\mathrm{O}_{4}$ \\
\hline
\end{tabular}

Information:

$\mathrm{O}_{1}$ : The pretest results in the treatment group

$\mathrm{O}_{2}$ : The posttest results in the treatment group

$\mathrm{O}_{3}$ : The pretest results in the control group

$\mathrm{O}_{4}$ : The posttest results in the control group

X: Treatment

Sugiyono (2017: 79)

Researchers conducted research on two groups namely treatment groups and control groups. This study was conducted in two lessons with the description below:

1. At the beginning of the lesson, the researcher gives a pretest to the two groups. Pretest is used to measure students' early skills. 
2. After that, the researcher conducted the teaching and learning activities with the two groups. Treatment groups will be given action in their learning activities by using visual quantum learning model. While the control group, in the learning is done by class.

3. After that, the researcher gives posttest to the two groups. Posttest is used as a measure of students' ability after learning and to observe student learning outcomes after being given action on treatment groups and classical learning in the control group.

This research was conducted at SDN Sidokumpul and SDN Pucang IV Sidoarjo. Both places are randomly selected from 6 schools located within SD Negeri Se-Gugus 01 Sidoarjo. Implementation of this research is done in class IV in academic year 2017/2018 in even semester.

The population of this study is all the fourth grade students in SD Negeri Gugus 01 Sidoarjo as many as 372 students, while the sample used in this study is 122 students obtained from fourth graders in SDN Sidokumpul which amounted to 61 students as experimental group and fourth grade students in SDN Pucang IV Sidoarjo counted 61 students as a control group.

The research instrument used in this research is questionnaire sheet, observation sheet, test question, validation sheet, and documentation. Instrument requirements are considered valid and reliable is to test the validity and reliability test. In the validity test, the researcher used SPSS 13.0 program with product moment correlation test formula. One of the formulas used in SPSS 13.0 is the Bivariate Pearson correlation. In this study, researchers used a significance level of 5\% (95\% acceptance rate). An instrument is said to be valid if $\mathrm{Sig} \leq \alpha$ or product-moment correlation coefficient $>$ r-table. This means that if sig $\leq 0.5$ then the instrument is declared valid and vice versa if sig $\geq 0.5$ then the instrument proved invalid. In addition, researchers can use the product moment correlation coefficient. If the correlation coefficient of product moment $>$ r-table, then the instrument is declared valid, and vice versa. In the reliability test, researchers also used SPSS 13.0 program with Alpha Cronbach formula. The steps that should be done by the researcher in using Alpha Cronbach formula are as follows: (1) calculate the score variant of each item, (2) summing the variance of all items, (3) calculate reliability index using Alpha Cronbach formula.

The next step, after obtaining the reliability index is to consult the reliability index with r-table product moment. Instruments are said to be reliable if the reliability index Alpha Cronbach $>0.6$, then the instrument is proven reliable (Wiratna and Endrayanto, 2012: 186).

Based on the results of trials conducted at SDN Pucang V in class IV $\mathrm{B}$, there are $\mathrm{N}=30$ using SPSS 13.0 significant level $5 \%$ obtained rtable $=0.361$. The item is said to be valid if rcount $>$ table so that the test result obtained is valid. In accordance with the calculation of the validity of test questions that amounted to 40 problems. Then the test results of the valid questions will be used as a question instrument in the experimental and control groups.
Item question that has passed the validity test then tested the reliability of the instrument in question. Reliability test is used to determine the consistency level of the instrument's answer. Calculation of this instrument using SPSS 13.0. The result of the calculation of the reliability coefficient of 20 items for pretest is 0.758 and the calculation result for the posttest question is 0.832 . Determination of instrument reliability level using signification level set with alpha $60 \%$ or 0,6 . If the reliability value of Alpha Cronbach $>0.6$, then the instrument is declared reliable (Sujarweni and Endrayanto, 2012: 186).

\section{B. Data Analysis Techniques}

In the $\mathrm{N}$ - Gain calculation obtained from the pretest and posttest scores on each experimental group and control group. Increased competence that occurs before and after learning is calculated by the formula $\mathrm{g}$ factor or better known as $\mathrm{N}$ - Gain. The following N - Gain formula according to Meltzer [6] is as follows:

$$
\mathrm{g}=\frac{\text { score posttest }- \text { score pretest }}{\text { score maks - score pretest }}
$$

Information:

g : score of $\mathrm{N}-$ Gain

score posttest: score in post-test

score pretest: score in the pre-test

score max: score maximal

After the results are obtained, they are then interpreted into the following categories according to Hake [6] presented in Table 3.3 below:

\section{TABLE I. INTERPRETATION CLASSIFICATION $N$-GAIN}

\begin{tabular}{|c|l|}
\hline Percentage & Interpretati \\
\hline $\mathrm{g}>0,7$ & High \\
\hline $0,3<\mathrm{g}<$ & Medium \\
0,7 & \\
\hline $\mathrm{g}<0,3$ & Low \\
\hline
\end{tabular}

Homogeneity test is performed at the beginning of data analysis (pretest). Homogeneity test is a test on the sample to know the object under study (sample) has the same variant or not. The following homogeneity test formula used in testing the homogeneity of group variants are:

Varian $\mathrm{SD}^{2}=\frac{\sum X^{2}-\left(\sum X\right)^{2} / N}{(N-1)}$

Information:

$\mathrm{SD}^{2}$ : score variants

$\sum \mathrm{X}^{2}$ : total data of $\mathrm{X}^{2}$

$\sum X$ : total data of $\mathrm{X}$

$\mathrm{N}$ : The sum of all data 
Next, interpret the homogeneity test result (F) with table F values. The object under study (sample) is said to be homogeneous if Fmax $<$ Ftable [7].

The normality test or Chi-square has two functions namely, it can be used to perform the assessment and to examine the hypothesis. Normality test aims to test the significance of the difference in frequency or to see whether the population of the distribution data is normal or not. Therefore, the researcher used Chi-square formula to know the normality of the research distribution. Here is the Chi-square formula used by researchers, namely:

$$
x^{2}=\Sigma\left[\frac{(f o-f r e e)^{2}}{f e}\right]
$$

Information:

$\mathrm{x}^{2}$ : score of chi-square

fo: obtained frequency

fe: expected frequency

The data is declared normal if $\mathrm{X} 2<\mathrm{X} 2$ table. So the Chisquare value can be used in interpreting whether there is a visible difference or not between the frequency obtained with the desired frequency in the population [7].

Different test using t-test technique, that is a statistical technique used to know the significance of the difference of two samples, that is two average obtained from two the spread. The following t-test formula is as follows:

$$
t-t e s t=\frac{\bar{X}_{1}-\bar{X}_{2}}{\sqrt{\left[\frac{S D_{1}^{2}}{N_{1}-1}\right]+\left[\frac{S D_{2}^{2}}{N_{2}-1}\right]}}
$$

Information:

$\bar{X}_{1} \quad$ : Mean on the first sample distribution

$\bar{X}_{2}$ : Mean on the second sample distribution

$S D_{1}^{2}$ : The variance value of the first sample distribution

$S D_{2}^{2}$ : The variance value of the second sample distribution

$N_{1}$ : Total individuals in the first sample

$N_{2}$ : Total individuals in the second sample

And then the value of the t-test obtained is correlated with table value. To check the value of the t-test, it must first find the degrees of freedom $(\mathrm{db})$ first. So the hypothesis is accepted if t-test $>$ table. This means that if the test results are greater than table, then the hypothesis research ( $\mathrm{Ha})$ accepted and operational hypothesis (Ho) rejected [7].

\section{RESULT AND DISCUSSION}

\section{A. Initial Stage Analysis}

In the initial analysis, calculation of normality test with criteria used for $5 \%$ significant level and $\mathrm{db}=\mathrm{n}-1$. If symbol " $\leq$ " then the data distribution is normal and vice versa if symbol " $\geq$ " then the distribution data is not normal. The following table results of normality test:

\begin{tabular}{|c|c|c|c|c|}
\hline Group & $\chi_{\text {hitung }}^{2}$ & $b^{\text {d }}$ & $\chi_{\text {tabel }}^{2}$ & $\begin{array}{l}\text { Informa } \\
\text { tion }\end{array}$ \\
\hline $\begin{array}{l}\text { Experi } \\
\text { ment }\end{array}$ & 19,00 & \multirow{2}{*}{$0^{6}$} & \multirow[t]{2}{*}{79,1} & Normal \\
\hline Control & 8,66 & & & Normal \\
\hline
\end{tabular}

TABLE II. A RESULT OF THE FIRST NORMALITY TEST

From the above table it is known that the test of normality of pretest value in experimental group (class IV SDN Sidokumpul) for significant level $\alpha=5 \%$ with $\mathrm{db}=61-1=60$, obtained $=19.00$ and $=79,1$. Because $\leq$ it can be concluded that the data distribution is normal. While normality test of pretest value in control group (class IV SDN Pucang IV) for significant level $\alpha=5 \%$ with $\mathrm{db}=61-1=60$, obtained $=8,66$ and $=79,1$. Because $\leq$ it can be concluded that the distribution data is also normal.

Furthermore, the calculation of the homogeneity test on pretest data. Both groups have the same variant when using a significant level of $5 \%$ with the terms Fcount $<$ Ftable, then it can be said that the data is homogeneous. From the calculation of variant obtained:

$$
\begin{aligned}
& s_{1}^{2}=126,90 \\
& s_{2}^{2}=108,64
\end{aligned}
$$

Then it can be calculated in the following formula:

$$
F_{\text {count }}=\frac{126,90}{108,64}=1,17
$$

From the calculation of homogeneity test for the sample obtained $\mathrm{F}_{\text {count }}=1.17$, with $5 \%$ significant level and $\mathrm{db}$ of the numerator $=60$ and $\mathrm{db}$ denominator $=60$ that is $\mathrm{F}_{\text {table }}=1.50$. It

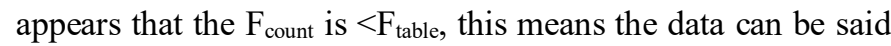
to be homogeneous.

In this final data analysis, the researcher uses N-Gain calculation to know the improvement of student learning result. Based on the data obtained, shows that the value changes from pretest to posttest. Furthermore, the values obtained were analyzed to find the average of learning outcomes, gains, and $\mathrm{N}$-gain briefly in table 3 . 
TABLE III. RESULT COGNITIVE LEARNING

\begin{tabular}{|c|c|c|c|c|c|}
\hline Group & $\mathrm{e}^{\operatorname{Pr}}$ & ${ }_{\text {ost }}$ P & $\operatorname{ain}^{G}$ & $\begin{array}{c}N- \\
\text { gain }\end{array}$ & $\begin{array}{l}\text { Categ } \\
\text { ory of } N \text { - } \\
\text { gain }\end{array}$ \\
\hline ent & $.03^{68}$ & $.16^{80}$ & $.13^{12}$ & 376 & m Mediu \\
\hline Control & $.95^{67}$ & $.2^{73}$ & $25^{5 .}$ & $\begin{array}{r}0 \\
164\end{array}$ & Low \\
\hline
\end{tabular}

The table shows that the average pretest before the learning was 68.03 in the experimental group and 67.95 in the control group. Further increased in the posttest with the average experimental group is 80.16 and the control group is 73.2. then the gain value in the experimental group is 12.13 and the control group is 5.25. while the $\mathrm{N}$-Gain in each group was 0.376 in the experimental group and the Control group was 0.164. in the experimental group, the results include a moderate category. Then the N-Gain interpretation in the control group is a low category. Furthermore, the obtained value of the t-test calculation.

Based on the calculation of research results obtained with significance level $\alpha=5 \%$. Ho testing criteria accepted if $>$ because in this study $=3.41$ and $=2.00$ and this means $\geq$, then Ha accepted. This means Ho: then the average value of cognitive learning outcomes of IPA on the materials of force and motion with visual quantum learning model in the experimental class is higher than the average value of learning with classical learning.

Different test results obtained by condition through the calculation of normality test and homogeneity test first. In the end-of-stage data normality test, normality test results are obtained:

TABLE IV. THE RESULT OF THE FINAL NORMALITY TEST

\begin{tabular}{|c|c|c|c|c|}
\hline Group & $\chi_{\text {hitung }}^{2}$ & b & $\chi_{\text {tabe }}^{2}$ & $\begin{array}{l}\text { Informati } \\
\text { on }\end{array}$ \\
\hline $\begin{array}{l}\text { Experim } \\
\text { ent }\end{array}$ & $99^{21,}$ & $d$ & 79 & Normal \\
\hline Control & $57^{12,}$ & 0 &, 1 & Normal \\
\hline
\end{tabular}

From the above table it is known that the normality test of posttest value in experimental group (class IV SDN Sidokumpul) for significant level $\alpha=5 \%$ with $\mathrm{db}=61-1=60$, obtained $=21,99$ and $=79,1$. Because $\leq$ it can be concluded that the data distribution is normal. While normality test of posttest value in control group (class IV SDN Pucang IV) for significant level $\alpha=5 \%$ with $\mathrm{db}=61-1=60$, obtained $=$ 12,57 and $=79,1$. Because $\leq$ it can be concluded that the distribution data is also normal.

Then on the homogeneity test, the two groups have the same variant when using a significant level of $5 \%$ with the terms Fcount $<$ Ftable, then it can be said that the data is homogeneous. From the calculation of variant obtained:

$$
\begin{aligned}
& s_{1}^{2}=124,14 \\
& s_{2}^{2}=120,86
\end{aligned}
$$

Then it can be calculated in the following formula:

$$
F_{\text {hitung }}=\frac{124,14}{120,86}=1,03
$$

\begin{tabular}{|c|c|c|c|c|}
\hline o. $\mathbf{N}$ & Group & tung & $\underset{\text { tabel }}{\mathbf{F}}$ & n Informatio \\
\hline 1 & Experiment & \multirow{2}{*}{03} & \multirow{2}{*}{$\begin{array}{c}1 \\
, 50\end{array}$} & \multirow{2}{*}{$\begin{array}{l}\text { Homogeno } \\
\text { us }\end{array}$} \\
\hline 2 & Control & & & \\
\hline
\end{tabular}

TABLE V. THE RESULT OF FINAL HOMOGENEITY TEST

From the calculation of homogeneity test for the sample obtained Fcount $=1.03$, with $5 \%$ significant level and $\mathrm{db}$ of the numerator $=60$ and $\mathrm{db}$ denominator $=60$ ie Ftable $=1.50$. It appears that the $\mathrm{F}$ count is $<$ Ftable, this means the data can be said to be homogeneous.

\section{PICTURE I. PRETEST AND POSTTEST}

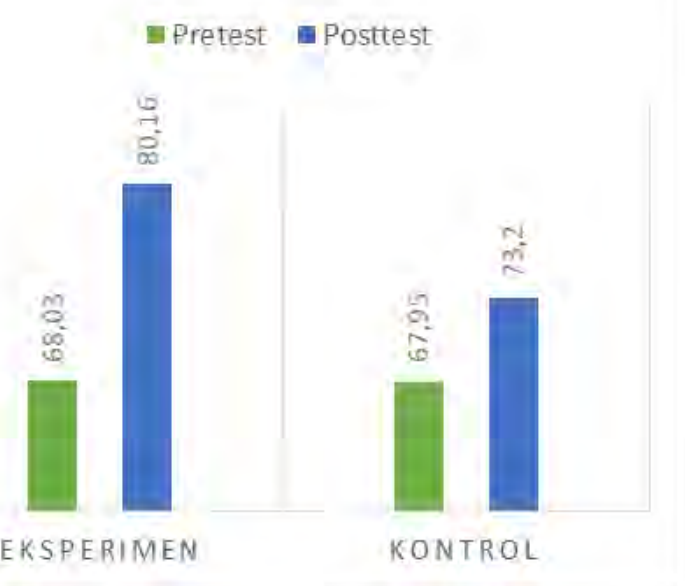

PICTURE 2. N-GAIN

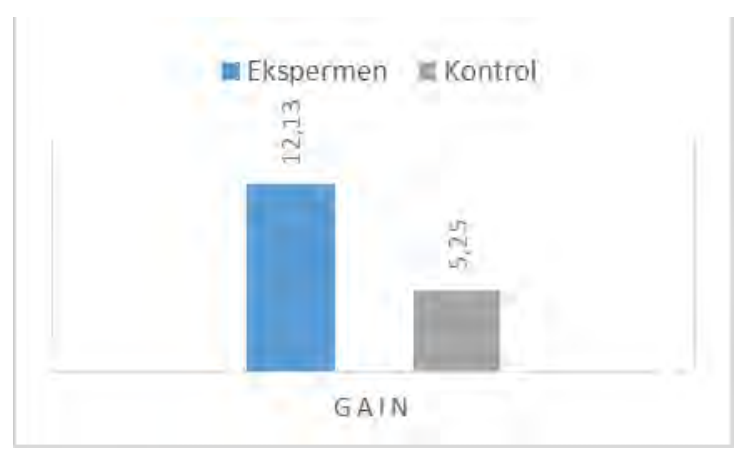




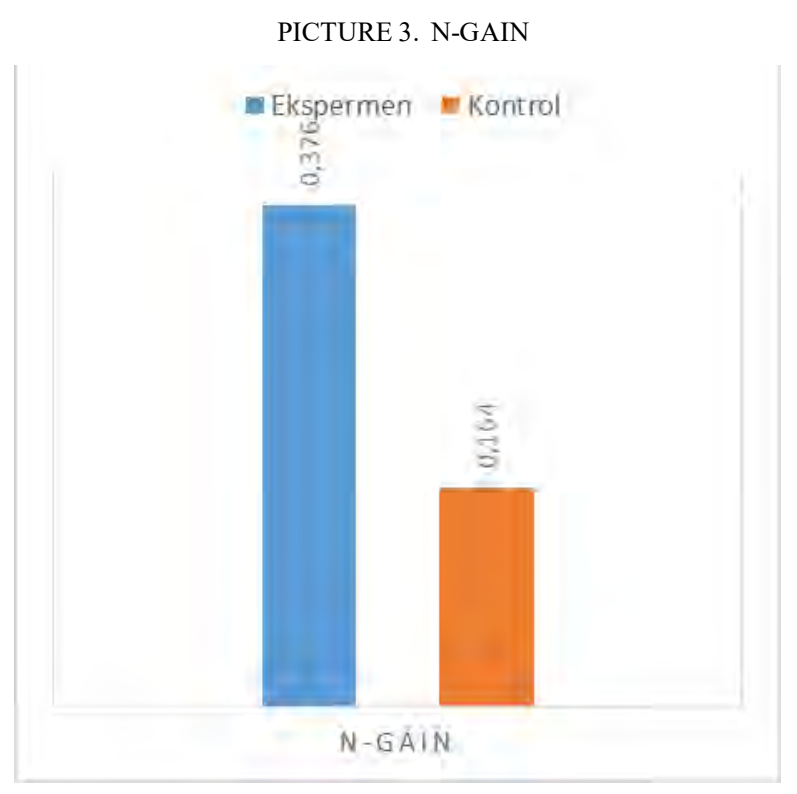

Based on the calculation, the average value of the pretest test for the experimental group is 68.03 with the standard deviation $(\mathrm{SD})=11.26$. While the average value of pretest in the control group was 67.95 with standard deviation (SD) $=$ 10.42. After the data obtained from both groups, then researchers do N-Gain calculations to determine the increase in student learning outcomes after the given behavior. The NGain calculation result was 0.376 in the experimental group which was in the medium category and 0.164 in the control group was in a low category.

The researchers then conducted a different test between the experimental group and the control group that had obtained the normal and homogeneous data. Different tests were used using the t-test formula. The result of the t-test is 3,41 . Ho testing criteria accepted, if $\leq$. Because this study obtained $\geq$, then Ha accepted and Ho rejected. Therefore, this research is known that the learning result of the learning model of visual in experiment class has a significant difference to the learning result of classical learning in control class.

The success of this learning process can be achieved because of the good orientation between teachers and students. Teachers are able to develop learning models that involve students so that students play an active role in learning. The development of the learning model creates a comfortable and enjoyable learning moment for students so that students are able to achieve optimal learning outcomes.

In practice, this learning model can improve the cooperation of learning motivation, and cooperation among learners so as to create an active learning atmosphere. With these active learning conditions, their learning outcomes can increase. This is in accordance with the principle of quantum learning model proposed by DePorter \& Mark [8] that is 'enter the world of students', the interaction between students and teachers able to make a bridge between two worlds namely the world of children and the world of learning. Initially, at the beginning of learning, students are invited to pray and grow a sense of interest and motivation in learning. In this phase, the teacher utilizes the visual modalities of the students by showing the media of concrete objects or images. So in the students have a desire to know more about the learning materials that will be received. In this early phase called Tumbuhkan.

This is in accordance with the opinion of Deporter [3] which states that each individual has three learning styles, one type of learning style is a visual learning style where a person who has this visual learning style should see in advance the facts that are going on to then be able to believe it is through illustration of images, videos, and others. Then in the next phase, students formed groups and discussed LKPD. Students observe LKPD sheets, exchange ideas and follow LKPD work instructions to solve problems. Students experience their own knowledge, receive and process the material given by the teacher. So that the student is able to make it a good learning experience for him/her. Through experience, students will easily remember what they have received. Through experience, have long-term memories that will help students remember the lessons they receive. This phase is called Alami.

After experiencing, students will define their own meaning of the learning it does. In this phase, students in groups work out the LKPD and work together to answer the questions available in LKPD. Students name each of the lessons learned. Students mean learning done, this is a stage Namai.

Students then demonstrate the lessons learned. In this phase, students present the results of the discussion from the results of LKPD practice. Students who become respondents pay attention and respond to the results of the discussions that are read in front of the class. Through demonstration, the learning received will be inherent in the memory of the students because it has done, not just knowledge but also associate knowledge with experience and name.

This is called Demonstration. Then the students do the repetition of learning materials that have been accepted. In this phase, students are asked in advance by the teacher, if anyone has not understood about learning today. If anyone does not understand, then the teacher can guide students and repeat on things that are not understood, students. Meanwhile, when students feel understand all, it can be done a question and answer about the material that has been taught that day and associated with previous learning, and can also be associated with the application of learning in everyday life. Repetition is done so that students master the learning materials provided and students will not feel afraid of losing experience. In this repeat phase, it can train students to to remember the memory. This is in accordance with retention theory, according to Chaplin (2002) which states that memory is the ability of a person to recall information that has been learned and that have been stored in the brain.

Finally, namely Celebrate. Everything the students do either because of their personal will or because it is demanded by the teacher to do so is worth celebrating. The celebration can be a verbal or material appreciation. In the learning process, 
students who can appreciate the effort and show perseverance, then the students deserve rewards. Generally, rewards can directly be a word of praise and applause or small actions such as stroking the head or giving a thumb.

However, at the end of learning, students are given rewards in the form of snacks because rewards are given in groups. The application of quantum learning model in accordance with the planning framework is TANDUR in the idea by DePorter [8]. DePorter's research framework conforms to Spenger's opinion in his book entitled "How to Teach To Keep Students Remember" (2011: 9-11) which is one of the teaching methods states that elaborative and repetition exercises can improve long-term memory. Where material is remembered is associated with the experience or other information that has been stored in memory, making it much more effective.

This research has been done previously by several researchers but with different research sites. In the application of this learning model, the researcher uses visual modalities as a supporting quantum learning model. Dawood Al Hamdani [4] argues that learning styles can improve students' learning and understanding of learning outcomes with particular instructional models. In research, Ni Made Rai [9] also has studied about quantum learning and the result obtained is the result of science learning students increased significantly compared with the results of science learning students with conventional learning model.

After applied visual quantum learning model, the motivation of learners to study science more increase. Because in the learning process the learner is more enthusiastic and enthusiastic in following the lesson than just with the lecture method only. This means that in the learning process they are able to accept what has been learned, it can't be separated from the student's modality which is mostly visual modality. So that learning results can be increased optimally.

Teachers do not fully provide a teaching material to students raw, but teachers help and guide students to be able to learn actively. Students discuss each other with the problem of simple invention or inquiry so that it can be generalized together. In accordance with the opinion of Susanto [10] that learning science is a process of teaching and learning based on principles, processes that can foster a scientific attitude toward students so that students can get their own invention and experience in performing a simple investigation.

Teachers in this process only guide students in the discovery process of answers in case of a difficulty. This means that students not only hear teacher information but can play an active role (student-centered) to explore and enrich their understanding of the concepts learned and apply them to new situations or different contexts (experiences) especially IPA. Thus the learning process is no longer merely knowing the knowledge of the teacher to the students but is a process of conceptual understanding that is oriented to the involvement of students actively with the environment and experience.

\section{CONCLUSION}

Based on the discussion of the results of research can be concluded that there is a significant influence visual quantum learning model on the results of learning IPA class IV in elementary. This is indicated by the mean value of cognitive learning outcomes in the dominant experimental group rather than the control group 80.16 with 73.2 . Increased cognitive learning outcomes in the experimental group obtained the value of $\mathrm{N}$-gain of 0.376 is included in the category of moderate and in the control group obtained $\mathrm{N}$-gain of 0.164 which fall into the low category. Psychomotor learning result of the experimental group got the average value of 83.81 on learning 1 and 80.12 in learning 2. While the learning result of psychomotor of the control group on learning 1 was 81.56 and in learning 2 was 79.3. in other words, in every learning, there is an increase in learning outcomes in the experimental group. Significant differences between the experimental group and the control group can be proven from the t-test calculation ie count of 3.41 larger than table at $\mathrm{db}=60$ with $5 \%$ significance level of 2.00. Thus the working hypothesis in this study accepted that states that the influence of visual quantum learning model of learning outcomes of science class IV in SD, while the null hypothesis in rejection.

\section{REFERENCES}

[1] N. Sudjana, "Penilaian Hasil Proses," 2011.

[2] S. B. Djamarah, "Psikologi belajar.” Jakarta: Rineka Cipta, 2002.

[3] D. Bobbi and M. Hernacki, "Quantum learning membiasakan belajar nyaman dan menyenangkan," Bandung: Kaifa, 2002.

[4] D. Al Hamdani, "Exploring students' learning style at a Gulf University: a contributing factor to effective instruction," Procedia-Social Behav. Sci., vol. 176, pp. 124-128, 2015.

[5] M. Oflaz and T. Turunc, "The effect of learning styles on group work activities," Procedia-Social Behav. Sci., vol. 46, pp. 1333-1338, 2012.

[6] D. E. Meltzer, "The relationship between mathematics preparation and conceptual learning gains in physics: A possible 'hidden variable' in diagnostic pretest scores," Am. J. Phys., vol. 70, no. 12, pp. 1259-1268, 2002.

[7] T. Winarsunu, "Statistik dalam Penelitian Psikologi \& Pendidikan: Cetakan keempat." Malang: UMM Press, 2015.

[8] B. DePorter, M. Reardon, and S. Singer-Nourie, Quantum teaching. mempraktikkan quantum learning di ruang-ruang kelas. Kaifa, 2010.

[9] N. M. R. Astuti, I. K. Ardana, and I. B. S. Manuaba, "Pengaruh Model Quantum Learning Berbantuan Media Lingkungan terhadap Hasil Belajar IPA Siswa Kelas IV SD Gugus III Kerobokan Badung," Mimb. PGSD Undiksha, vol. 1, no. 1, 2013.

[10] M. P. Ahmad Susanto, Teori belajar dan pembelajaran di sekolah dasar. Kencana, 2016 